\title{
The legitimacy of corporate entrepreneurship: a structured literature review
}

\author{
Lutz Göcke $^{1} \cdot$ Kristina Hülsebusch $^{1} \cdot$ Matthias Menter $^{2}$ (1)
}

Received: 15 December 2020 / Accepted: 30 October 2021 / Published online: 17 November 2021

(c) The Author(s) 2021

\begin{abstract}
Corporate entrepreneurship (CE) is essential for today's firms and currently a topic of considerable interest within the business community. Although the magnitude of related studies has increased over the last years, research on CE is missing an integrated concept and a research agenda for understanding the dynamics of resource deployment and withdrawal, resulting from legitimacy within the organization. The objective of this study is to examine the determinants influencing the provision and withdrawal of resources in the context of corporate entrepreneurship and identify the underlying strategies for gaining legitimacy. Analyzing more than 30 years of research, we provide a multidimensional framework synthesizing the state-of-the-art of resource allocation and withdrawal in CE. Our findings suggest that CE entities undertaking legitimation efforts, to be perceived as a meaningful and trustworthy organizational element and receive active and passive support, is very important. Based on the structured literature review, we propose a legitimacy perspective on the resource dynamics in CE settings, to further advance our understanding of resource deployment and withdrawal within organizations.
\end{abstract}

Keywords Corporate entrepreneurship - Strategic entrepreneurship · Intrapreneurship $\cdot$ Legitimacy $\cdot$ Resource deployment $\cdot$ Resource withdrawal

JEL Classification L26 · O31 · O32

Matthias Menter

matthias.menter@uni-jena.de

Lutz Göcke

lutz.goecke@hs-nordhausen.de

Kristina Hülsebusch

kristina.huelsebusch@hs-nordhausen.de

1 Department of Economic and Social Sciences, University of Applied Sciences Nordhausen, Nordhausen, Germany

2 Faculty of Economics and Business Administration, Friedrich Schiller University Jena, Jena, Germany 


\section{Introduction}

Globalization increasingly changes competitive conditions and jeopardizes firms' market positions (Corbett et al. 2013; Teng 2007). Recent years have seen several examples of companies fighting for survival or even failing, due to their inability or unwillingness to adopt an intrapreneurial approach (Skarmeas et al. 2016). To succeed in the long term, companies must steadily develop new ideas and strategies (Kuckertz 2017). Therefore, those companies must anticipate opportunities for entering new markets and generate innovations faster than their best competitors (Srivastava and Lee 2005; Teng 2007; Zahra et al. 2000). This is exactly where corporate entrepreneurship comes into play.

Corporate entrepreneurship (CE) refers to the development of new businesses within established firms (Hitt et al. 1999; Zahra et al. 2000). To be precise, it covers all incumbent-firm activities that aim at enhancing the organization, including its organizational structures, to increase its innovative ability and pave the way for new businesses to exist in the long term (Corbett et al. 2013; Kuckertz 2017; Zahra et al. 2000). Corporate entrepreneurship thus manifests itself in different CE entities inside a corporation that strive to generate innovations-for example, internal or external venturing practices, programs, or units (Kuratko et al. 2017). Firms cannot survive if they are not ready to put their gains back into play, to conquer new markets, develop new technologies, and create new business models (Schulte 2021). Corporate entrepreneurship may address all these difficulties (Bouchard and Fayolle 2017; Zahra et al. 2000). To overcome underlying challenges and develop the necessary core competencies for today and tomorrow, companies have increasingly relied on CE over the past few years to foster innovation (Corbett et al. 2013; Zahra et al. 2000). Although many companies are setting up CE initiatives, low survival rates characterize many CE entities (Ahuja 2019; Kelley 2011). For example, after only three years of operation, Coca-Cola closed its Founders incubator in 2016 (Miller 2016).

Despite the increased magnitude of studies on CE over the last years, "[...] much remains to be revealed about how corporate entrepreneurship is enacted in organizational settings" (Kuratko and Audretsch 2013, p. 324). The entrepreneurship literature often recognizes that legitimacy is a prerequisite that helps to preserve (financial) resources (Ma et al. 2016; Zimmerman and Zeitz 2002). Therefore, legitimacy is defined as "a generalized perception or assumption that the actions of an entity are desirable, proper, or appropriate within some socially constructed system of norms, values, beliefs, and definitions" (Suchman 1995, p. 574). Various studies developed over the past years (Kuratko et al. 2017; Moizer and Tracey 2010; Zimmerman and Zeitz 2002) attempt to understand the role that (external) legitimacy plays for start-ups, to attract resources from labor sources, venture capitalists, or governments (Moizer and Tracey 2010; Wang et al. 2017; Yiu and Lau 2008). In the context of corporate entrepreneurship, organizational entities must be equipped with the necessary resources to support the exploration and exploitation of entrepreneurial opportunities through new internal corporate ventures (Garrett and Neubaum 2013; Ma et al. 2016). However, the concept of legitimacy has received 
little attention in the field of corporate entrepreneurship, despite its importance in undertaking legitimation efforts that lead to obtaining necessary support. Thus, CE entities must gain legitimacy in the eyes of their stakeholders (Wang et al. 2017; Yiu and Lau 2008; Zimmerman and Zeitz 2002). Not reaching or losing legitimacy from stakeholders will ultimately lead to a withdrawal of resources and perhaps even project failure (Clark and Ramachandran 2019). Therefore, legitimation plays a major role in the allocation of resources. We apply the concept of (internal) legitimacy to structure the research on resource deployment and withdrawal in the context of corporate entrepreneurship, to advance our understanding of the survival or failure of CE entities.

To analyze the current state-of-the-art of (internal) legitimacy in corporate entrepreneurship, we conducted a structured literature review to address the following research question: What research exists on understanding the (internal) legitimacy and resource allocation of CE entities? Accordingly, this study examines the strategies leading to (internal) legitimacy within the organization, enabling the preservation of resources and increasing the survivability of CE entities. Our findings suggest the great importance of $\mathrm{CE}$ entities undertaking legitimation efforts to receive necessary resources, to use for innovation endeavors with such results as new internal corporate venture growth. Our contribution is thereby threefold. First, we introduce the concept of legitimacy as a mechanism to explain the survival or failure of $\mathrm{CE}$ entities. Second, we map the existing literature on CE resource deployment and withdrawal to a multidimensional legitimacy framework. Third, we identify future avenues of research that could further enhance the understanding of legitimacy, resource deployment and withdrawal, and survival of CE units.

The remainder of this paper is structured as follows. The next section provides the theoretical foundations for our research and describes the relevance of the research topic. Section three presents the methodological approach with the detailed procedure of our structured literature review and the sample of journal articles our study included. Section four discusses the most important findings, based on the developed multidimensional legitimacy framework. A final section concludes and outlines implications as well as future avenues of research.

\section{Theoretical background}

\subsection{Corporate entrepreneurship}

Corporate entrepreneurship is an umbrella term for all entrepreneurial activities of incumbent firms at the individual-team or organizational-unit level (Bouchard and Fayolle 2017; Zahra et al. 2000), which have the potential to create competitive advantages (Corbett et al. 2013; Covin and Miles 1999; Teng 2007). Therefore, corporate entrepreneurship functions as a special form of entrepreneurship and represents an independent concept that transmits entrepreneurial behavior of the individual to the organizational level (Bouchard and Fayolle 2017). Renewing established companies enables them to remain viable. This can occur through utilizing various innovation-based initiatives (Corbett et al. 2013), including, for example, corporate 
venture capital and corporate venturing, as well as general innovations and strategic renewal approaches (Röhm 2018; Weiss and Kanbach 2021; Zahra et al. 2000). The great potential for companies to renew their strategy or develop new ideas through corporate entrepreneurship entities has led to increasing interest in this approach. Many companies have already recognized that a basic entrepreneurial attitude is advantageous when it comes to dealing with the challenges of an increasingly turbulent business environment (Skarmeas et al. 2016).

In its initial phase, corporate entrepreneurship was not recognized as a separate field of research. Previous research shows that it took about 10 years for this research field to become established (Sakhdari 2016). Over the past few years, corporate entrepreneurship has attracted considerable attention that the changing economic and globalized environment has driven (Teng 2007). Due to its increasing relevance, corporate entrepreneurship research has attracted the attention of many scholars from the social sciences, particularly in terms of a common understanding of the field, its antecedents and outputs, the boundary conditions, or the scope of this construct (Hitt et al. 1999; Hornsby et al. 2002; Sakhdari 2016). However, with the emergence of this field, researchers have created a great deal of uncertainty by utilizing various definitions and demarcations. Scholars have tried to define the field of $\mathrm{CE}$ over the past few decades. In the beginning, mixed views appeared on the scope of corporate entrepreneurship because it was not clearly differentiated from the phenomenon of innovation or new product development within firms (Corbett et al. 2013; Sakhdari 2016). This is why such terms as intrapreneurship (Skarmeas et al. 2016), corporate venturing (Burgelman 1985; De Bettignies and Chemla 2008; Gutmann 2019), or strategic renewal (Hitt et al. 2011) are often synonymous with corporate entrepreneurship. This circumstance contributes to the great complexity of this field.

Despite much research devoted to corporate entrepreneurship, "there remains a greater need for further research about corporate entrepreneurship in organizational settings" (Kuratko et al. 2015: 245). Prior research identifies conditions that support corporate entrepreneurship behavior (see Marvel et al. 2007): (1) rewards, (2) management support, (3) resource availability, (4) organizational structures, and (5) risk acceptance or risk-taking culture. Kuratko et al. (1990) reduce these five factors from prior research to three-(1) managerial support, (2) organizational structure, and (3) reward and resource availability - while Hornsby et al. (2002) identify five factors that foster entrepreneurial activity within established companies: (1) management support, (2) work autonomy, (3) rewards, (4) time availability, and (5) organizational boundaries. These results already indicate that resources and top management are crucial elements within the domain of corporate entrepreneurship. Some researchers suggest that these conditions encourage experimentation and, therefore, impact employees' motivation to develop and commercialize their innovations (Hornsby et al. 2002; Marvel et al. 2007). As legitimation is crucial for the allocation of resources, we expect the concept of legitimacy to help us structure findings on the organizational settings and to guide future research on the development of corporate entrepreneurship (Clark and Ramachandran 2019; Ito 2018; Wang et al. 2017). 


\section{2 (Internal) Legitimacy and resource allocation}

Organizational theorists have long discussed how important it is for a company to gain legitimacy in its respective environment, to ensure its organizational survival (Ito 2018; Suchman 1995). Legitimacy allows the corporation to attract important resources from stakeholders in the organizational context (Clark and Ramachandran 2019; Zimmerman and Zeitz 2002). However, similar to corporate entrepreneurship, a multitude of different definitions of the concept of legitimacy exist. Suchman (1995) even speaks of a surprisingly weak conceptual anchoring and criticizes the lack of an examination of the definition of legitimacy. Referring to Suchman's (1995) underlying definition, we assume that an organization that achieves legitimacy appears to various stakeholders as more meaningful and trustworthy. Accordingly, legitimacy affects how people act toward an organization. In the case of new entrepreneurial ventures, this results in the provisioning of resources from various stakeholders-financial, intellectual, or relational capital alike (Zimmerman and Zeitz 2002).

Following Kostova and Zaheer (1999), Kostova and Roth (2002), and Drori and Honig (2013), we distinguish internal legitimacy from external legitimacy. In the context of CE, internal legitimacy is particularly important. In the case of internal legitimacy, the object that gains legitimacy is not the organization itself but an organizational entity, e.g., a practice, program, unit, or strategy. Frandsen et al. (2013) investigate the internal legitimacy of sustainability programs, whereas other authors focus, for example, on marketing departments (Park et al. 2012), purchasing departments (Tchokogué et al. 2017), or subsidiaries (Kostova and Roth 2002). All these studies conclude that the actions of an organizational entity must comply with the socially constructed system of norms, values, beliefs, and definitions. The literature often recognizes internal legitimacy as a prerequisite for helping to preserve resources for internal objects (Clark and Ramachandran 2019; Ito 2018; O'Kane et al. 2015; Wang et al. 2017). For example, in the context of technology transfer offices (TTOs) of universities, legitimation plays a major role for the allocation of resources. Once legitimate, TTOs may have greater access to resources, while failure to establish legitimacy may result in the withdrawal of resources (O'Kane et al. 2015). However, external legitimacy also plays a role when it comes to corporate entrepreneurship units. Not only the organization but also the respective CE entity must undertake legitimation efforts to appear beyond organizational boundaries as a meaningful element.

Besides the different definitions and foci, a distinction is made between different forms of legitimacy. Suchman (1995) identifies three types of organizational legitimacy: (1) pragmatic legitimacy, (2) moral legitimacy, and (3) cognitive legitimacy. Suddaby et al. (2017, p. 454) note that pragmatic legitimacy "arises from an organization's capacity to achieve practical outcomes [for stakeholders] in its immediate environment". A company acquires pragmatic legitimacy in light of its importance for realizing the self-interests of reference groups and, according to a balance of incentives and contributions, when it creates a direct and/or indirect benefit for stakeholders who assign legitimacy to the company (Suchman 1995). The moral (or normative) legitimacy of a company refers to the normative evaluation of 
its actions by stakeholders. ${ }^{1}$ Therefore, the basis of the assessment is not a specific benefit derived from an interaction with the company, but rather the stakeholders' moral value system. For example, an organization can gain normative legitimacy by demonstrating that it addresses certain norms and values, such as fair treatment of employees, profitability, or networks, and thus receives resources (Zimmerman and Zeitz 2002). A company acquires cognitive legitimacy if it implements meaningful measures from the observer's point of view, i.e., behaves rationally in terms of the relevant environment (Suchman 1995). In the case of cognitive legitimacy, a new venture tries to signal that its identity supplies what is needed or desired and will succeed in the business sector where it is allegedly active. For example, the assumption that a qualified founder and top management team will be advantageous to the new venture may lead to achieving cognitive legitimacy (Zimmerman and Zeitz 2002).

Aldrich and Fiol (1994) identically describe these three types of legitimacy, but they add one more: regulative legitimacy, achieved when a company is operating according to rules, regulations, standards, and expectations. Thus, it often involves sanctions. Regulatory legitimacy is particularly important for new corporate ventures, but also for established companies. Failing to acquire regulatory legitimacy may prevent new ventures from operating legally, limiting their access to resources (Zimmerman and Zeitz 2002). Presumably, the legitimacy of the established organization affects the legitimacy of the CE entity; the withdrawal of an organization's regulatory legitimacy makes it difficult to maintain for the $\mathrm{CE}$ entity that belongs to the company.

Based on these descriptions, this paper distinguishes between four types of legitimacy: (1) pragmatic, (2) normative, (3) cognitive, and (4) regulative legitimacy.

\section{Methodology}

To define the state-of-the-art of resource allocation and withdrawal in CE, we developed a structured literature review (SLR), covering more than 30 years of research on corporate entrepreneurship. We chose a qualitative research design for the research methodology, a specific method that helps to analyze data so that it allows for clear conclusions about what is known and what is not known about a specific research topic (Booth et al. 2012; Denyer and Tranfield 2009). An SLR is particularly well suited to our research because it is a widely accepted method for evaluating existing literature regarding a specific issue (Fisch and Block 2018). In addition, the procedure has significant considerations, including "clarity, validity, and auditability" (Booth et al. 2012: 19).

Therefore, we chose a structured literature review as our core methodological approach for this research and divided the procedure into three overarching steps (see Tranfield et al. 2003): (1) planning the review, (2) conducting the review, and

\footnotetext{
1 Following Zimmernan and Zeitz (2002), we consistently use the term "normative" legitimacy instead of "moral" legitimacy in the subsequent sections, to describe this normative evaluation of actions.
} 
(3) reporting and dissemination. Access to the first step was gaining an overview of relevant literature and concepts within the field of corporate entrepreneurship. Derived from this general overview, we defined the goal of our research and identified important keywords. We based our initial search on the VHB-JOURQUAL 3, a rating of business-related journals based on judgments of members of the German Academic Association of Business Research (VHB). We chose this ranking due to its quality assessment, which allowed us to focus our search only on highquality journals assessed as $\mathrm{A}+, \mathrm{A}$, or $\mathrm{B}$, according to the VHB-JOURQUAL 3 rating. Thus, we deliberately excluded from our review book chapters, book reviews, proceedings, and working papers. Aiming to understand the dynamics of resource deployment and withdrawal in corporate entrepreneurship entities, we conducted two types of analyses. First, we used criterion sampling based on keyword searches in general business administration, strategic management, and innovation, technology, and entrepreneurship journals, such as Academy of Management Journal, Academy of Management Review, Management Science, Research Policy, Journal of Business Venturing, Entrepreneurship Theory and Practice, Journal of Product Innovation Management, Strategic Management Journal, Journal of Management, and Long Range Planning (see Table 1).

We performed the search within the different databases by using the keywords appearing in the title, abstract, or keywords of the respective journal articles. We followed Morris et al. (2011) and Lampe et al. (2020), who both categorize the corporate entrepreneurship literature into several streams. Whereas Morris et al. (2011) argue that $\mathrm{CE}$ manifests in companies through corporate venturing and strategic entrepreneurship, Lampe et al. (2020) differentiate between entrepreneurial orientation, intrapreneurship, entrepreneurial management, and strategic entrepreneurship. Thus, we utilized the following keywords: "corporate entrepreneurship", "corporate venturing", "strategic entrepreneurship", "intrapreneurship", "entrepreneurial management", and "entrepreneurial orientation". Our search covers research from initial publications in 1985 until the beginning of 2020, identifying 723 articles in this period (see Table 1). Some articles appear twice in this evaluation because of some overlap in the keywords. For this reason, eliminating duplicates was necessary. Second, to search for possible relationships, we combined the results from the corporate entrepreneurship literature with keywords in the abstract of the articles from two distinct categories: legitimacy-related keywords and outcome-related keywords (see Table 2). The two different keyword categories reflected our motivation to synthesize the research on legitimacy and acceptance on the one hand and, on the other hand, the resource-related outcomes. Overall, a total of 399 articles were identified.

As our aim was to understand legitimacy and its outcomes, we scrutinized each article by carefully reading the abstract and the introduction. Sometimes, we read additional sections of the paper to ensure an optimal fit with the objective of this review. Finally, we included in our review 78 articles that were useful for answering our research-guiding question and, thus, focused on the legitimation of activities or the allocation of resources in the context of corporate entrepreneurship. The keywords "resources", "capital", "support", and "top management" especially created some noise in the review process. Figure 1 provides an overview of our SLR approach. 


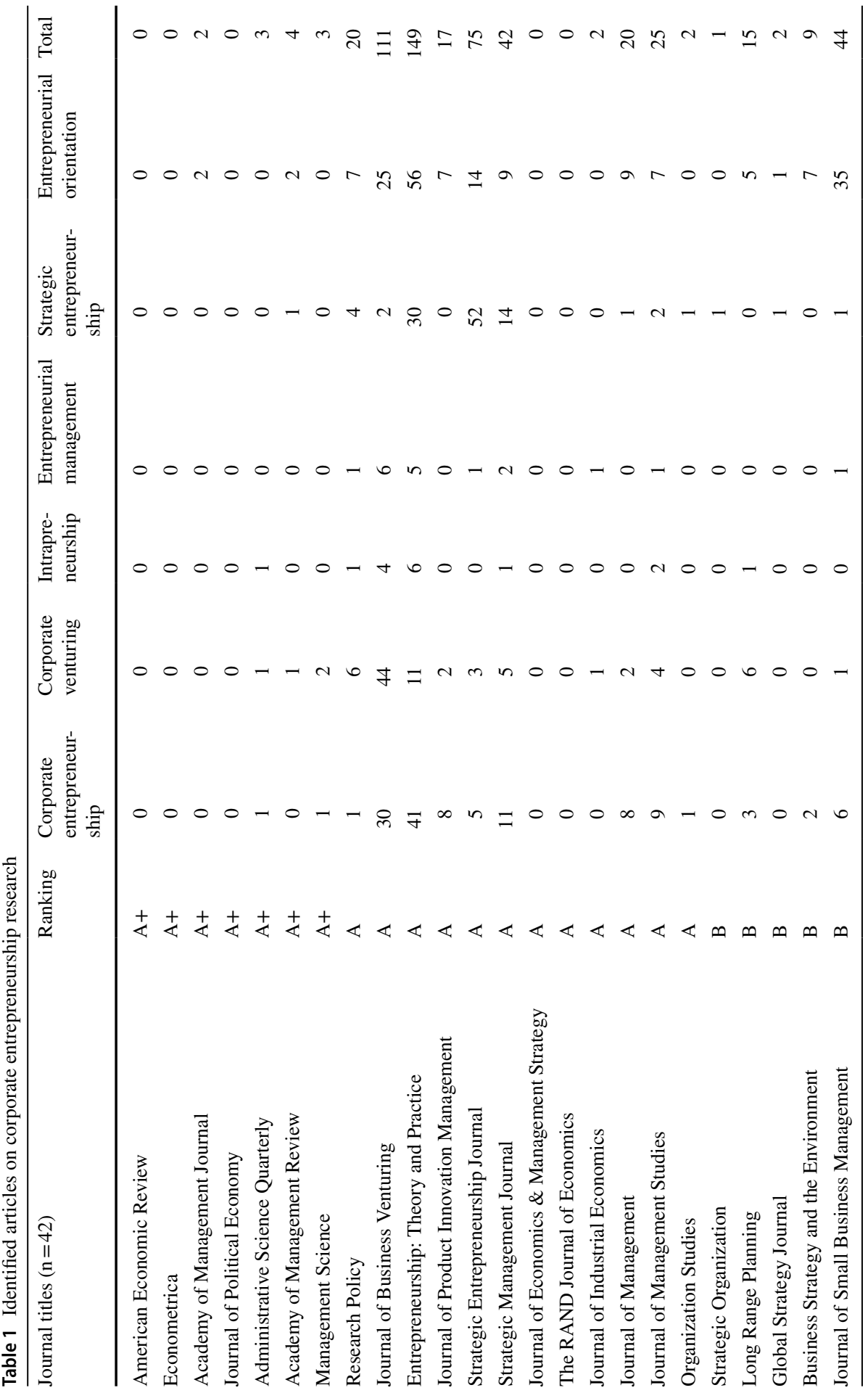







Table 2 Identified articles based on interface analysis

\begin{tabular}{|c|c|c|c|c|c|c|c|}
\hline $\begin{array}{l}\text { Keyword } \\
\text { searches } \\
(n=723)\end{array}$ & $\begin{array}{l}\text { Corporate } \\
\text { entrepreneur- } \\
\text { ship }\end{array}$ & $\begin{array}{l}\text { Corporate } \\
\text { venturing }\end{array}$ & $\begin{array}{l}\text { Intra- } \\
\text { preneur- } \\
\text { ship }\end{array}$ & $\begin{array}{l}\text { Entrepre- } \\
\text { neurial } \\
\text { management }\end{array}$ & $\begin{array}{l}\text { Strategic } \\
\text { entrepre- } \\
\text { neurship }\end{array}$ & $\begin{array}{l}\text { Entrepre- } \\
\text { neurial } \\
\text { orientation }\end{array}$ & Total \\
\hline \multicolumn{8}{|c|}{ Legitimacy-related } \\
\hline Legitimacy & 1 & 0 & 1 & 1 & 2 & 2 & 7 \\
\hline Legitimation & 1 & 0 & 1 & 0 & 0 & 1 & 3 \\
\hline Approval & 0 & 1 & 0 & 1 & 0 & 1 & 3 \\
\hline Acceptance & 2 & 0 & 0 & 1 & 1 & 2 & 6 \\
\hline Commitment & 4 & 3 & 3 & 0 & 1 & 7 & 18 \\
\hline $\begin{array}{l}\text { Encourage- } \\
\text { ment }\end{array}$ & 0 & 0 & 0 & 0 & 0 & 0 & 0 \\
\hline $\begin{array}{l}\text { Top-manage- } \\
\text { ment }\end{array}$ & 14 & 2 & 3 & 2 & 2 & 21 & 44 \\
\hline $\begin{array}{l}\text { Middle-man- } \\
\text { agement }\end{array}$ & 3 & 1 & 2 & 0 & 0 & 0 & 6 \\
\hline \multicolumn{8}{|c|}{ Outcome-related } \\
\hline Survival & 5 & 2 & 1 & 0 & 3 & 9 & 20 \\
\hline Continuation & 0 & 0 & 0 & 1 & 0 & 0 & 1 \\
\hline RESOURCES & 25 & 23 & 5 & 11 & 20 & 38 & 122 \\
\hline Capital & 13 & 15 & 1 & 5 & 10 & 23 & 67 \\
\hline Support & 27 & 13 & 3 & 3 & 5 & 21 & 72 \\
\hline Allocation & 0 & 2 & 0 & 0 & 1 & 5 & 8 \\
\hline Deployment & 0 & 1 & 0 & 1 & 0 & 2 & 4 \\
\hline Funding & 2 & 2 & 1 & 2 & 4 & 2 & 13 \\
\hline Financing & 1 & 0 & 0 & 1 & 0 & 2 & 4 \\
\hline Withdrawal & 1 & 0 & 0 & 0 & 0 & 0 & 1 \\
\hline Total & 99 & 65 & 21 & 29 & 49 & 136 & 399 \\
\hline
\end{tabular}

Whereas research on legitimation concepts and reviews on CE and resource allocation exist (Miller et al. 1991; Yiu and Lau 2008), this paper addresses an existing research gap, focusing on the determinants influencing the provision and withdrawal of resources in the context of corporate entrepreneurship and identifying the underlying strategies for gaining legitimacy. Concentrating on CE entities, this paper especially sheds light on the employees and managers in an organization, reviews various existing research efforts, and creates a knowledge base for future research.

\section{Findings}

Organizations strive for legitimacy for many reasons, and conclusions about the importance, difficulty, and efficacy of legitimation efforts usually depend on the goals against which these efforts are measured. Some researchers identify legitimation as helping to overcome limitations (Wang et al. 2017) and highlight its vital role 


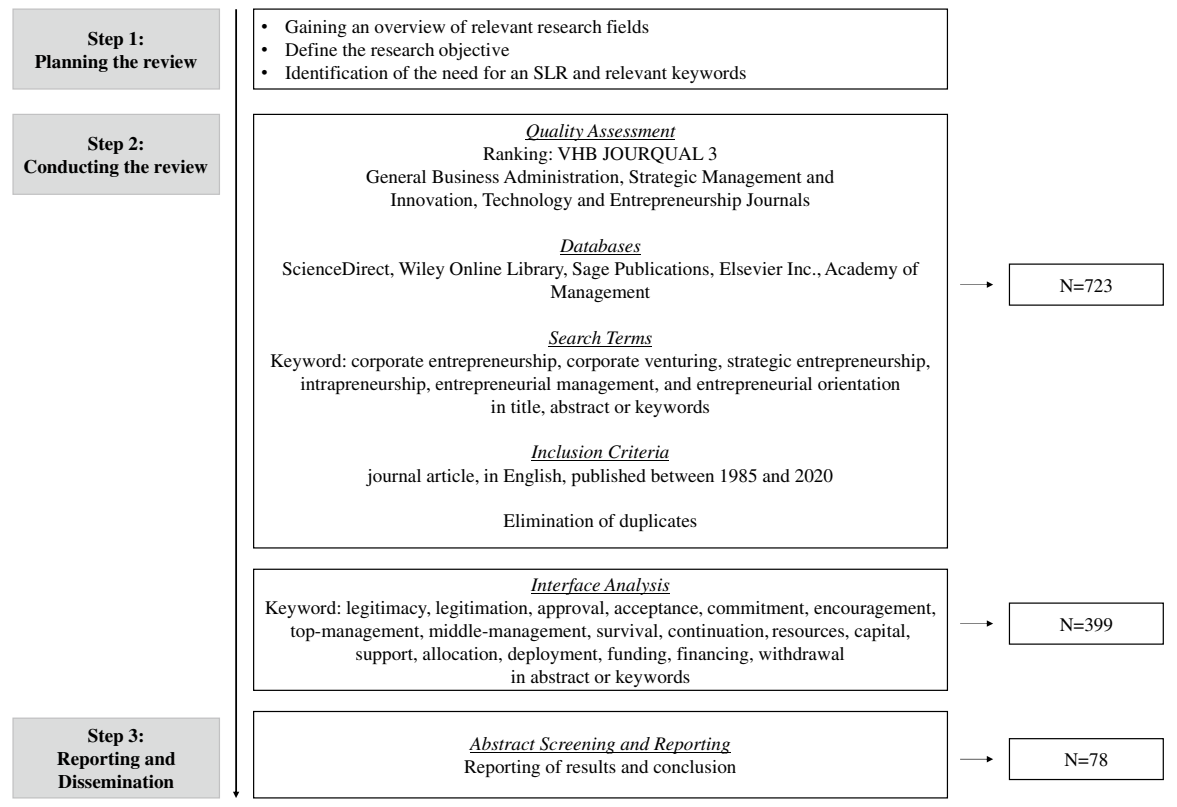

Fig. 1 Approach for structured literature review

in organizational survival and success in the CE context (Clark and Ramachandran 2019; Corbett et al. 2007). Therefore, businesses need to undertake legitimation efforts to meet stakeholder requirements. The identified articles leveraged various theoretical perspectives on investigating resource allocation in the field of corporate entrepreneurship. Only a small amount of research is rooted in institutional theory (Tracey et al. 2018; Yang and Wang 2013) or discusses the concept of (internal) legitimacy explicitly (Clark and Ramachandran 2019; Moizer and Tracey 2010; Wang et al. 2017). Although the existing corporate entrepreneurship research does not widely apply the concept of legitimacy, we found much research that discusses strategies for gaining internal acceptance for corporate entrepreneurship within an organization (Halme et al. 2012; Hill and Birkinshaw 2008; McGrath 1995; O'Kane et al. 2015). Further research examines the outcomes of this acceptance (Basu and Wadhwa 2013; Hayton 2005; Srivastava and Lee 2005; Yusubova et al. 2019) and possible conditions for legitimacy inside a corporation (Kuratko et al. 2017; Ravasi and Turati 2005; Tenzer and Yang 2020), thus contributing implicitly to the concept of legitimacy in the context of corporate entrepreneurship.

To structure the synthesis of the results, we follow the definition of Suchman (1995: 574) and specify legitimacy in the context of CE as follows:

Legitimacy of corporate entrepreneurship entities describes the acceptance of the actions of a corporate entrepreneurship entity by the relevant stakeholders because the actions are perceived as desirable, proper, or appropriate within the socially constructed system of norms, values, beliefs, and definitions. 
Based on the previously described distinction between cognitive, normative, regulative, and pragmatic legitimacy (Aldrich and Fiol 1994; Suchman 1995), we utilize these types of legitimacy in the context of corporate entrepreneurship to structure the existing literature.

A CE entity achieves cognitive legitimacy, when it implements meaningful measures to achieve the objectives of internal stakeholders. Failure to meet performance objectives likely results in withdrawal of legitimacy and resources. For example, a corporate incubation program set up to support the ideation and implementation of new corporate ventures, but seeing no venture implemented, could experience a loss of cognitive legitimacy. In the context of $\mathrm{CE}$, normative legitimacy is the perceived conformity of the CE entities' actions with the normative system of its stakeholders. Conflict with the stakeholders' normative values likely results in the revocation of normative legitimacy. For example, a CE entity consistently supporting ventures incompatible with the ethical standards of the core organization could result in a withdrawal of normative legitimacy. Normative legitimacy can help new entities to enhance their relationships with key stakeholders, by addressing their interests, norms, and values (Wang et al. 2017) and, thus, acquire access to needed resources. Regulative legitimacy in the context of $\mathrm{CE}$ is perceived adherence to important regulations-legal regulations relevant to any member of the national/industrial context (e.g., data protection, corruption) or regulations inside the company (e.g., discrimination, working hours). Abuses against these regulations will shrink regulative legitimacy or result in its total withdrawal. Thus, gaining approval and endorsement from governments and industrial associations (Wang et al. 2017, p. 376) can achieve obtaining regulative legitimacy. Hence, CE entities adopt practices and procedures of existing and successful concepts to signal that the corporate venture has succeeded as well. Pragmatic legitimacy of CE entities is acceptance based on the direct values that the $\mathrm{CE}$ entity provides to the individual stakeholders in the project. If it generates no direct value for the stakeholders, acceptance predictably shrinks over time. A CE entity thus must have importance for the stakeholders' realization of their self-interests, creating benefits for them that gain the entity its pragmatic legitimacy (Suchman 1995).

To synthesize the literature on legitimacy in the context of corporate entrepreneurship, we leveraged our research question on resources and an entity's strategies for gaining legitimacy, to develop a multidimensional legitimacy framework (see Fig. 2). With this approach, we identified strategies for CE entities to gain legitimacy and associated outcomes. Furthermore, we identified trade-offs between the types of legitimacy and considered feedback mechanisms between the dimensions of our model. As the entrepreneurial organizational context decisively affects CE strategies and outcomes, we further took account of the entrepreneurial orientation of organizations, which seems to mediate CE legitimacy (see Miao et al. 2017). We thereby assume that entrepreneurial orientation positively affects CE strategies' effectiveness, as well as the quality and quantity of resources allocated to CE entities (De Clercq et al. 2013; Engelen et al. 2016; Jiang et al. 2018; Wiklund and Shepherd 2003; Wu et al. 2008).

In the following sections, we describe the potential strategies for $\mathrm{CE}$ entities to gain legitimacy, including the trade-offs that can arise. Based on these 


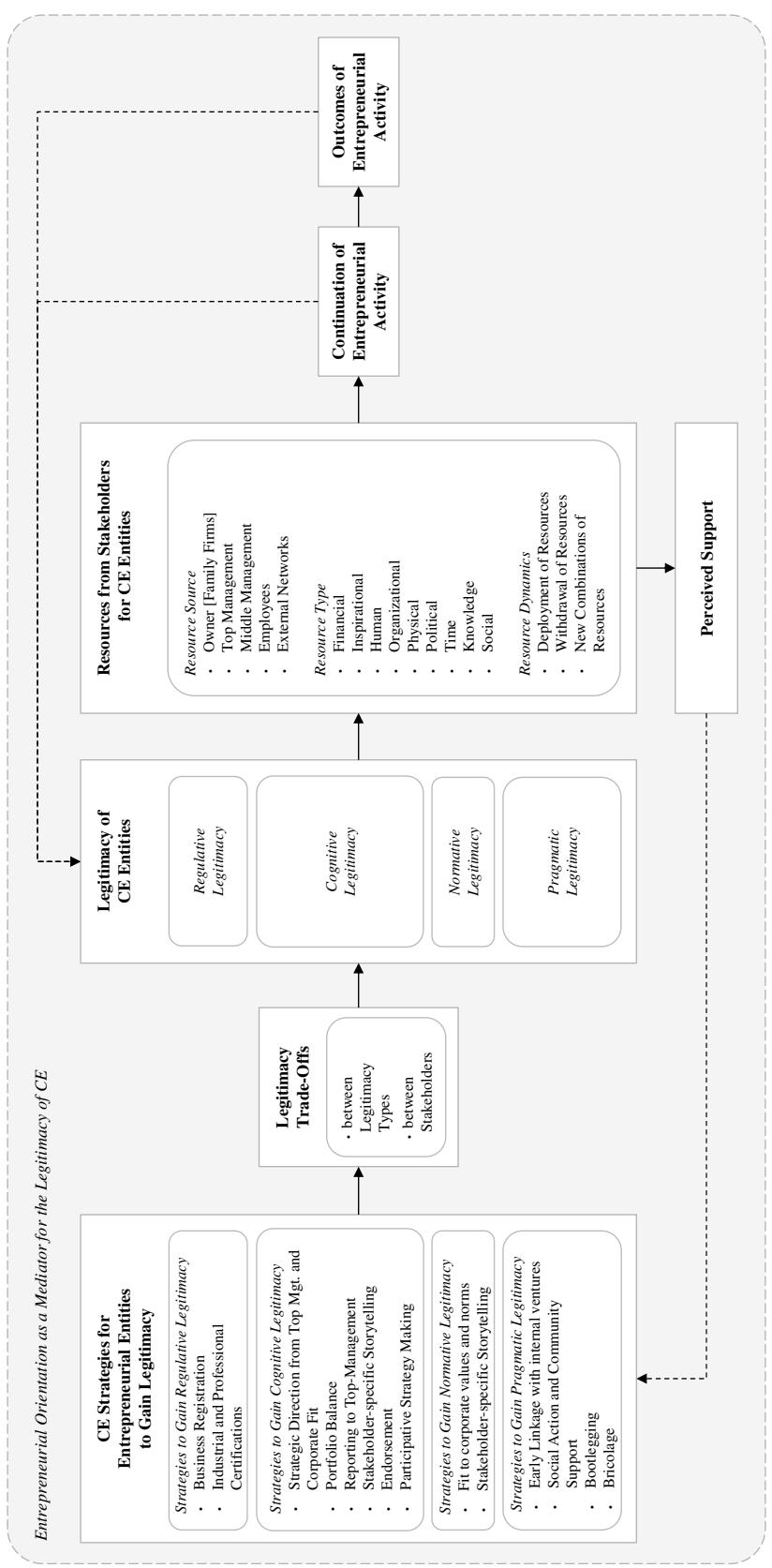

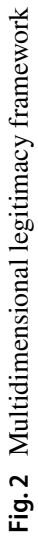


legitimacy strategies, we discuss the outcomes of legitimacy in the context of CE and the feedback mechanisms that inform strategy-making and legitimacy itself (see Appendix 1).

\subsection{Strategies of corporate entrepreneurship entities to gain legitimacy}

To legitimize their activities, $\mathrm{CE}$ entities can make various efforts to gain and maintain acceptance inside the corporation. In this section, we aim to synthesize the strategies of CE entities that align with the different types of legitimacy. In our case, managers of a CE entity use legitimation strategies to influence the allocation of resources.

Regulative legitimacy is an urgently required condition for organizations and entities within an organization that want to act on the market and create trust within an ecosystem. For this reason, regulative legitimacy provides the basis for every CE entity action. One strategy for new (internal) ventures demonstrating that the $\mathrm{CE}$ unit is operating according to rules, regulations, standards, and expectations, thus gaining regulative legitimacy, refers to business registrations or industrial and professional certifications (Wang et al. 2017). An internal corporate venture signaling its compliance with guidelines and regulations reduces uncertainty, and the corporate venture can gain regulative legitimacy. When it comes to innovative products, one major barrier is the ambiguity that a lack of standards causes (Ravasi and Turati 2005; Wang et al. 2017). Therefore, regulative legitimacy can help CE entities to overcome those barriers and exploit new business opportunities. During our research, we noticed fewer findings on regulatory legitimacy than on the other types of legitimacy. Therefore, these results are less comprehensive in the context of corporate entrepreneurship.

Strategies for achieving cognitive legitimacy intentionally indicate that a $\mathrm{CE}$ entity implements meaningful measures and contributes to the organization's performance. Our analysis shows that if top management must decide whether to support an internal corporate venture, one decisive factor is corporate fit (Behrens and Patzelt 2016; De Sarbo et al. 1987; Shrader and Simon 1997). Strategic direction from top management determines new product opportunities in which to invest and which to abandon (De Massis et al. 2021; Spanjol et al. 2011). This strategic direction serves (for instance) as a filter for potential champions to decide whether they support a new entrepreneurial opportunity. Projects that could create greater resistance receive less support from management (Bertels et al. 2020). Thus, a strategy for managers of $\mathrm{CE}$ entities is to comply with the strategic direction from top management and ensure a corporate fit. Furthermore, Behrens and Patzelt (2016) identify the balance of a CE portfolio as an important factor in continuing $\mathrm{CE}$ activities. Managers of CE entities must ensure pursuing not only incremental but also radical $\mathrm{CE}$ projects. The progress of the CE entity is particularly important for achieving cognitive legitimacy inside the organization. Continuous reporting to top management can thereby increase its acceptance (McGrath 1995). This reporting should inform top managers on different dimensions, e.g., market worth, firm worth, and competitive insulation, to holistically update the progress of a $\mathrm{CE}$ entity (McGrath 
1995). To increase the effect of the legitimation effort, managers of CE entities can try to establish a direct reporting line to top management. SLR findings also show that high levels of reporting to top management tend to diminish the performance of a new venture, in terms of cost and quality advantages; the highest venture performance occurred in subsamples with low reporting levels (Miller et al. 1991). Our SLR shows that to maintain the acceptance of top managers, showing them results is more likely to get them involved (Vandermerwe and Birley 1997).

The existing literature on corporate entrepreneurship attributes great importance to top management support, but our SLR shows that meeting the requirements of other stakeholders is also necessary to gain cognitive legitimacy (Kuratko et al. 2015, 2017). Consequently, our research reveals that these stakeholders must be continuously convinced to provide the necessary resources to the CE entity (Di Domenico et al. 2010). Stories can be an effective way for CE entities to communicate the activities in a favorable and convincing manner (Lounsbury and Glynn 2001). Specifically framing stories to the expectations of the stakeholders can secure the resource flow (Fisher et al. 2017) and create a distinctive image. Lounsbury and Glynn (2001) find that entrepreneurs must intelligently construct a story that makes clear what the company stands for and how their resources will lead to future benefits for the stakeholders, to gain legitimacy and access to resources. Hence, we see the development of stakeholder-specific stories, to gain and maintain cognitive legitimacy from these stakeholders, as an additional strategy for managers of CE entities.

Moreover, one possible strategy for achieving cognitive legitimacy is endorsement, where positive press reports or endorser competencies (Ito 2018) signaling that the entity is trustworthy can impact the legitimation process. Results from Ito (2018) show 13 examples of resource mobilization through endorsement by external individuals or firms. Decisive factors were: (1) credibility of the evaluation of the new business's technology or products by a prominent firm or individual, (2) credibility of the evaluation of the need for the new business or its commercial potential, due to a prominent firm initiating business discussions or becoming a customer, and (3) referencing and using an endorser's economic and/or social status. Another strategy that we identified through the SLR is the participative strategy-making for a CE entity that includes the CE managers and its different stakeholders. Chirico et al. (2011) identify the importance of this in the context of multigenerational family firms, where different resource commitments require different family generations.

The strategies for achieving normative legitimacy show some overlaps with strategies for achieving cognitive legitimacy. If an organization can prove that it deals appropriately with norms and values, such as fair treatment of employees, endorsement and networks, or profitability, it can gain normative legitimacy and, thus, access to resources. We identify corporate fit, in the sense of conformance with the norms and values of a corporation, as an important strategy for CE entities (De Sarbo et al. 1987; O'Kane et al. 2015). Stakeholder-specific storytelling can help to convince stakeholders to accept potential differences between values and norms of the overall organization and those of the CE entity (Lounsbury and Glynn 2001; O’Kane et al. 2015).

Furthermore, pragmatic legitimacy is important to the allocation of required resources to $\mathrm{CE}$ entities. As discussed, the corporate entrepreneurship entity 
acquires pragmatic legitimacy by its importance for reference groups realizing their self-interests and, according to a balance of incentives and contributions, creating a direct and/or indirect benefit for stakeholders who, in turn, assign legitimacy to the organization (Suchman 1995). McGrath (1995) shows that the development of an early linkage between the CE entity and the firm can result in acceptance by the parent organization. Thus, we see developing an early linkage as a potential strategy for CE entities. Moizer and Tracey (2010) show that an increase in social action can lead to an increase in organizational legitimacy. In turn, this leads to an increase in community support, which is then reflected in larger stocks of capital that can be re-invested in social actions. Moizer and Tracey (2010) refer to this as the organizational legitimacy loop. Notably, a time lag exists between social action and its resulting benefits. The findings on the organizational legitimacy loop align closely with the work of Venugopal and Viswanathan (2019), describing the phenomenon of organizations often entering local contexts by connecting themselves with high-status gatekeepers. By connecting with legitimate actors in the local ecosystem, they can gain legitimacy (Venugopal and Viswanathan 2019). Therefore, presumably, social actions, bootlegging (Globocnik and Salomo 2015), and bricolage (Halme et al. 2012) can strongly impact CE entities in terms of pragmatic legitimacy. The literature shows that bricolage seems to be one possible answer to different kinds of resource shortages (Halme et al. 2012). In this case, bricolage describes how employees, as soon as they encounter difficulties, bundle and combine their own resources to push their idea forward: "When faced with constraints the bricoleur draws upon resources at hand to overcome the obstacles, perhaps in an unconventional way" (Halme et al. 2012, p. 5). Moreover, they are often so motivated that they use their own free time, take risks regarding their career, and ask for no compensation for their efforts. Hence, some overlaps with bootlegging behavioremployees engaging in activities without official permission or supervision-appear (Augsdorfer 2005; Globocnik and Salomo 2015). They provide their own resources, with the intention of remaining unnoticed, and ignore formal communication channels to promote their ideas. Bootlegging activities are hidden and, therefore, difficult to control through managerial measures (Globocnik and Salomo 2015). Because the organization does not legitimize those activities, employees lack formal access to resources.

To gain legitimacy, CE entities can implement different strategies. Interestingly, most strategies discussed focus on conformance with the set of rules or norms that different stakeholders develop. CE entities enhance their legitimacy with a strong corporate fit, the adherence to regulative and normative rules, or direct benefit for their stakeholders. Sparse research discusses the manipulation of conditions in favor of the activities that CE entities develop. Zimmerman and Zeitz (2002) identify conformance and manipulation as relevant strategies for new ventures that are highly important also in the context of corporate entrepreneurship. Furthermore, the results of bootlegging behavior and bricolage indicate that specific conditions can provoke unorthodox or even rule-breaking behavior, where a CE entity risks its legitimacy in one dimension (e.g., normative legitimacy) to build its legitimacy in another dimension (e.g., cognitive legitimacy). We describe these constellations as trade-offs between different legitimacy types and different stakeholders, which managers of CE 
entities must consider when deciding on a particular strategy. Biniari (2011) shows this trade-off with the example of envy. One department getting more support than another, perhaps through strong cognitive legitimacy, may cause envy that could risk its normative legitimacy. The observations by top management of envy between organizational members and the corporate entrepreneurs could lead to skepticism and possibly influence the perceptions and behavior of top management toward the venturing program, thus influencing its normative legitimacy (Biniari 2011). In another example, Sykes and Block (1989) show that if a company only promotes socially compatible individuals (normative legitimacy), the CE entity might risk the loss of innovators, which could result in lower performance and, thus, a loss of cognitive legitimacy. These legitimacy trade-offs between legitimacy types and stakeholders as sources of legitimacy are an important aspect of corporate entrepreneurship, which future research should address.

\subsection{Outcomes}

Depending on the successful implementation of the described legitimacy strategies, CE entities either lose or gain resources. Based on our SLR, we can differentiate the sources and types of resources, as well as the resource dynamics that internal acceptance of the CE entity and its operations induce. In this context, we must consider the constant interaction between individual actors. Every stakeholder decides on the allocation of resources, whereby trade-offs often occur between allocating the resources to the core company or to the new venture (Basu and Wadhwa 2013). Within our framework, we subdivide the outcomes into three categories: (1) resource source, (2) resource type, and (3) resource dynamics.

$\mathrm{CE}$ entities can receive necessary resources from various sources of resources within an organization. Thus, organizational embeddedness can lead to various benefits, such as access to tangible resources through the network or learning benefits, emotional support, and legitimacy. To build and maintain organizational legitimacy, new companies can find engaging with local stakeholders advantageous (Moizer and Tracey 2010). Venugopal and Viswanathan (2019) describe the phenomenon of organizations often entering local contexts by associating themselves with highstatus gatekeepers (e.g., elected representatives, traditional leaders, government representatives). Given the high barriers to commercialization of scientific knowledge, intermediaries can have special importance for entrepreneurial units and be helpful when companies need to resolve financial constraints. Thus, organizations that manage to exist in highly developed institutional environments and succeed in becoming isomorphic with the environment acquire the legitimacy and resources necessary to exist in the long term (Meyer and Rowan 1977). Hence, when it comes to gaining legitimacy and access to resources in order to achieve a degree of integration within the organization, the entrepreneurial process depends to a large extent on different organizational members (Biniari 2011). As a result, our research distinguishes between various sources of resources that a $\mathrm{CE}$ unit can use. It can receive resources through resource orchestration in family firms (Chirico et al. 2011), top management (Hornsby et al. 2009; Rogan and Mors 2016; Srivastava and Lee 2005), and middle 
management (Halme et al. 2012; Hornsby et al. 2002; Kuratko et al. 2005), use its own resources (e.g., through employees) (Globocnik and Salomo 2015; Tenzer and Yang 2020), or tap external resources outside the corporation through external networks or complementary stakeholders (Clarysse and Bruneel 2007; Teng 2007). The willingness of each stakeholder to provide resources to the CE entity can vary according to the individual knowledge of the stakeholder (Dalziel et al. 2011).

Based on our SLR, we further identified different resource types of particular importance. As stated, support from management plays a major role in the provision of resources. Research shows that top management support, including the provision of financial resources, positively relates to the number of entrepreneurial ideas generated (Greene et al. 1999; Heavey and Simsek 2013; Hornsby et al. 2009). Moreover, top management support positively relates to organizational performance (Martin-Rojas et al. 2019). Also, top and middle managers play an important role in setting an organizational vision or environment that encourages innovation and benefits corporate entrepreneurship activities, hence, providing inspirational resources (Heavey and Simsek 2013; Hitt et al. 1999; Hornsby et al. 2002). Furthermore, top management support can result in additional human resources, with the assignment of talented managers or employees to the CE entity (De Bettignies and Chemla 2008). Whereas top managers are needed to support high-uncertainty/ high-risk ventures, middle managers are critical to the identification and acquisition of the right resources at the right time (Kuratko et al. 2005). Hence, managers must set the organizational conditions that support the entrepreneurial activities and provide (physical) infrastructure to support the entrepreneurial activities (Greene et al. 1999; Vandermerwe and Birley 1997). However, middle and top managers will only engage or support entrepreneurial behavior when the outcomes of these activities meet or exceed their expectations: "We expect, that the more positive this relationship [between entrepreneurial activities and expected outcomes] is perceived to be, the stronger is the resulting motivation to encourage entrepreneurial actions, either in the form of continued pursuit of the current projects or initiation of new projects" (Kuratko et al. 2005, p. 709). Furthermore, political resources-i.e., the support in political processes to mobilize scarce resources (Fulop 1991) or to protect the CE entity when breaking the rules (Greene et al. 1999) — are of great importance for a CE entity. Moreover, the time availability of critical stakeholders (Bertels et al. 2020; Hornsby et al. 2009) is a crucial resource type, in the context of corporate entrepreneurship. Knowledge is another critical resource for CE entities (Gassmann and Becker 2006; Gurău and Dana 2020). Intellectual capital and top management team diversity have a positive influence on innovation and venturing activities (Hayton 2005; Srivastava and Lee 2005). Thereby, top managers try to grow beyond the limits set by the resources they currently control, with the aim of acquiring more technology investment in their firm. Exploiting technologically skilled people and the development of technologically distinctive competencies increases corporate entrepreneurship (De Bettignies and Chemla 2008; García-Morales et al. 2014). However, managers invest not only company resources but also (individual) social resources in building beneficial relationships that have a positive impact on resource allocation. Individual engagement often realizes a wider network, resulting in more diverse opportunities (Rogan and Mors 2016). A (social) network is useful 
for finding further resources and offering trust, whereby bricoleurs especially make use of their various networks to mobilize resources (Teng 2007; Greene et al. 1999).

The different resource dynamics that the management or employees within an organization use can lead to either deployment (Basu and Wadhwa 2013) or withdrawal (O'Kane et al. 2015; Teng 2007) of resources. If a CE entity succeeds in convincing the management or stakeholders of its business idea, resource deployment will take place at different organizational levels. If the behavior or strategies of the organizational unit may increase the uncertainties, withdrawal of resources is one possible consequence. Apart from these two possibilities, employees often use the exploration of new combinations of resources as an alternative to further advance their innovative ideas, which also constitutes a qualifying characteristic of entrepreneurial action. In order to further develop their ideas despite the lack of resources, employees often make use of the organizations' hidden resources or generate their own resources (Burgelman 1983; Globocnik and Salomo 2015; Halme et al. 2012). Based on the perceived support the CE entity receives (Bertels et al. 2020; Zampetakis et al. 2009), the managers of a CE entity will choose their legitimacy strategies. Thus, CE managers will presumably repeat successful and avoid unsuccessful legitimacy strategies.

The CE entity receiving resources from stakeholders will lead to further consequences, such as the continuation of entrepreneurial activities, and ultimately to entrepreneurial outcomes. If a company receives the required resources, it can use them for the innovative project, which results, for example, in new venture growth. In addition, the literature review shows that entrepreneurial innovations seem more concerned with the exploration of new combinations of resources than with the optimization of existing ones (Westhead and Wright 1998). Bundling different resources rather than similar ones will allow new ways of doing business (Teng 2007). Firms owning a wide range of complementary resources are therefore more likely to achieve competitive advantages (first-mover benefits) (Srivastava and Lee 2005). Once a company has achieved legitimacy and gained access to all necessary resources, it can establish its entrepreneurial ideas on the market. The continuation of both entrepreneurial activities and outcomes also affects the legitimacy of CE entities. Hence, feedback mechanisms are significant in the context of legitimation.

\section{Conclusion}

Over the past few years, companies have increasingly relied on $\mathrm{CE}$ as a strategy to ensure survivability, whereby CE entities have become increasingly important in a turbulent globalized environment. However, research on $\mathrm{CE}$ is missing an integrated concept and research agenda for understanding the legitimacy of CE and the subsequent dynamics of intraorganizational resource deployment and withdrawal. Our structured literature review has addressed this research gap. We have identified the current state of research on strategies that impact the acquisition of legitimacy and the provision or withdrawal of resources for corporate entrepreneurship entities. Analyzing more than 30 years of research on corporate entrepreneurship, 
we developed a multidimensional framework by synthesizing the research on legitimacy and resource dynamics in the context of CE.

Our review offers an overview of relevant aspects of legitimation and corporate entrepreneurship. Our primary contribution is that legitimacy has outstanding significance for $\mathrm{CE}$ entities. CE entities undertake legitimation efforts to be perceived as a meaningful and trustworthy organizational element and, thus, worthy of receiving active and passive support. Our findings suggest that strategies and the behavior of the CE management team are key in gaining and maintaining legitimacy. Identifying strategies must consider that the choice of a strategy can depend on various influencing factors. The entrepreneurial orientation of a company and the nature of the company's environment also play a role in selecting strategies, which makes strategizing even more difficult and complex. Our research also revealed that there are currently no concrete characteristics by which to measure legitimacy, making it challenging to define precise actions that support its achievement.

Within the context of corporate entrepreneurship, the findings of our review have implications for scholars, managers, and employees. Analytically, we illustrated that corporate entrepreneurship entities are increasingly important and legitimation plays a key role in the allocation of needed resources. We highlighted the most important theoretical foundations and created a structured literature review, covering more than 30 years of research, representing the current state of research within the wide field of legitimacy and corporate entrepreneurship literature. Conceptually, this study provides a multidimensional framework synthesizing the state-of-the-art, to explain the strategies and outcomes of resource deployments for corporate entrepreneurship entities and their impact on legitimacy. In summary, our contribution is threefold. First, we introduced the concept of legitimacy as a mechanism that helps to explain the success or failure of a CE entity. Second, we have compiled the existing literature into a multidimensional legitimacy framework to explicate the strategies and outcomes of resource deployment for corporate entrepreneurship units and their impact on legitimacy. Third, based on our results, we identified various future research directions that could further enhance our understanding of legitimacy, resource deployment or withdrawal, and success factors for the survival of CE entities in general.

This study has some limitations. First, we rely on journal rankings to assess the quality of research. Despite its usefulness, Frey and Rost (2010) show the limited applicability of such rankings. Second, because of the great complexity of this research field, a reduction of complexity was first necessary to grasp the research field in its essence and entirety. Although we tried to include as many keywords as possible in this research, we cannot guarantee absolute completeness under the circumstances. Many definitions surround the understanding of corporate entrepreneurship and different views of legitimacy. This makes reducing the complexity and grasping the whole research field even more difficult. Third, in terms of the 
generalizability of our results, we recommend that other researchers expand and refine our findings. This particularly involves the need to empirically test the framework categories and subcategories within an entrepreneurial environment. We try to enable this through a transparent and generalizable process and the involvement of different sources and analytical approaches (Booth et al. 2012; Fisch and Block 2018).

After many efforts to understand legitimacy in the context of CE entities, our research tries to integrate the rather decoupled literature. Future research needs a shift of attention to further conceptualize the measurability and evaluation of legitimacy efforts in the context of CE. The effort should consider challenges regarding the overall process and selection of adequate strategies to gain legitimacy. Our research aims to clarify which strategies help to prevent different uncertainties and gain legitimacy in the corporate ecosystem. However, conflicts may exist between the strategies for obtaining different types of legitimacy. In this context, future research should identify different decision-making factors. Furthermore, it should examine in which context certain strategies are most effective, considering the respective type of legitimacy sought. The development stages of the CE entity as well as the relationship with the corporation should receive special attention. In addition, further efforts should investigate the foundations of legitimacy, e.g., determining what role the entrepreneurial orientation plays, and how the organizational environment can affect legitimacy in the context of CE entities. Our study already provides some insights into resource dynamics; future research should try to build a deeper understanding of them. In particular, it should consider how different structures of CE entities can affect legitimacy. Overall, the concept of strategies in the context of CE legitimacy requires more intensive consideration. Future research should reveal which strategies achieve which effects and how to measure these outcomes, also from a practical perspective. Furthermore, future research should shed light on the dynamics between conflicting CE strategies to gain legitimacy, e.g., achieving legitimacy through organizational conformance on the one hand and, on the other hand, stretching the cognitive, regulative, normative environment through rule-breaking/bootlegging behavior necessary to innovate. Table 3 summarizes the most promising avenues of future research, focusing on the legitimacy of corporate entrepreneurship. 


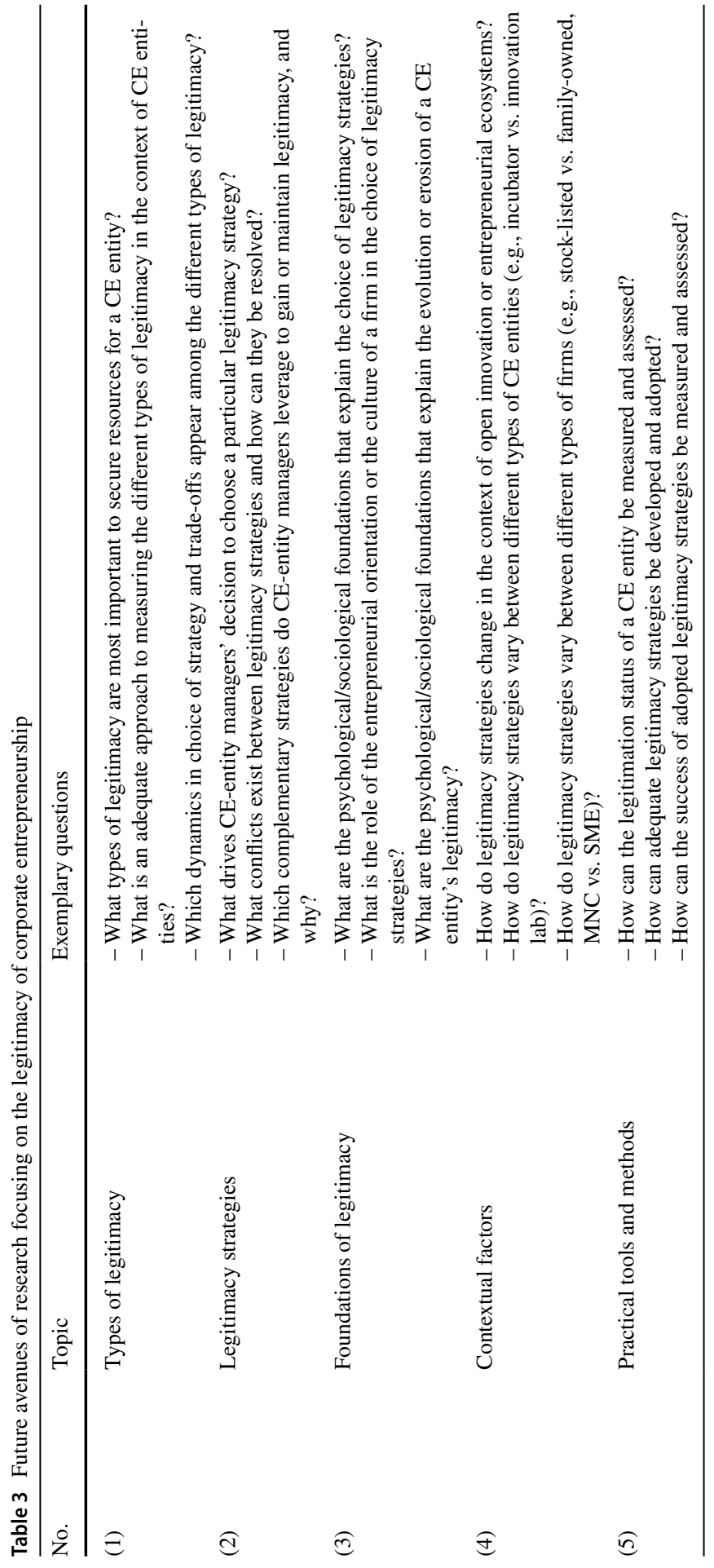




\section{Appendix 1}

\section{(1) Corporate entrepreneurship strategies to gain legitimacy}

\begin{tabular}{|c|c|c|c|}
\hline Type of legitimacy & Strategy & $\begin{array}{l}\text { Description of the } \\
\text { strategy }\end{array}$ & Studies \\
\hline Regulative legitimacy & $\begin{array}{l}\text { Business registration } \\
\text { Industrial and profes- } \\
\text { sional certifications }\end{array}$ & $\begin{array}{l}\text { One strategy for new } \\
\text { ventures to demon- } \\
\text { strate that the CE unit } \\
\text { is operating according } \\
\text { to rules, regulations, } \\
\text { standards, and expec- } \\
\text { tations are business } \\
\text { registration or indus- } \\
\text { trial and professional } \\
\text { certifications }\end{array}$ & Wang et al. (2017) \\
\hline \multirow[t]{5}{*}{ Cognitive legitimacy } & $\begin{array}{l}\text { Strategic direction given } \\
\text { by top management/ } \\
\text { Corporate fit }\end{array}$ & $\begin{array}{l}\text { Prior research found that } \\
\text { corporate fit dominates } \\
\text { all other factors in } \\
\text { terms of importance } \\
\text { for deciding if a cor- } \\
\text { porate venture will be } \\
\text { supported }\end{array}$ & $\begin{array}{l}\text { De Sarbo et al. (1987); } \\
\text { Sykes (1990); Shrader } \\
\text { and Simon (1997); Hill } \\
\text { and Birkinshaw (2008); } \\
\text { Behrens and Patzelt } \\
\text { (2016); Bertels et al. } \\
(2020)\end{array}$ \\
\hline & & $\begin{array}{l}\text { Deciding in which new } \\
\text { product opportunities } \\
\text { to invest and which to } \\
\text { forgo is determined by } \\
\text { the strategic direction } \\
\text { from top management }\end{array}$ & $\begin{array}{l}\text { De Massis et al. (2021); } \\
\text { Spanjol et al. (2011) }\end{array}$ \\
\hline & Portfolio balance & $\begin{array}{l}\text { Balancing the portfolio } \\
\text { with respect to radical } \\
\text { and incremental CE } \\
\text { projects is important in } \\
\text { deciding continuation } \\
\text { of an initiative }\end{array}$ & $\begin{array}{l}\text { Behrens and Patzelt } \\
\text { (2016) }\end{array}$ \\
\hline & $\begin{array}{l}\text { Reporting to top man- } \\
\text { agement }\end{array}$ & $\begin{array}{l}\text { Assess and report } \\
\text { progress on different } \\
\text { dimensions: market } \\
\text { worth, firm worth, and } \\
\text { competitive insulation }\end{array}$ & McGrath (1995 \\
\hline & & $\begin{array}{l}\text { High-level reporting } \\
\text { to top management } \\
\text { tends to moderate } \\
\text { the performance in } \\
\text { terms of the cost and } \\
\text { quality advantages of } \\
\text { a venture. The highest } \\
\text { venture performance } \\
\text { was observed in } \\
\text { subsamples with low } \\
\text { reporting levels }\end{array}$ & $\begin{array}{l}\text { Miller et al. (1991); Sykes } \\
\text { (1990) }\end{array}$ \\
\hline
\end{tabular}




\begin{tabular}{|c|c|c|c|}
\hline Type of legitimacy & Strategy & $\begin{array}{l}\text { Description of the } \\
\text { strategy }\end{array}$ & Studies \\
\hline & & $\begin{array}{l}\text { Top Managers open to } \\
\text { getting involved when } \\
\text { they see results }\end{array}$ & $\begin{array}{l}\text { Vandermerwe and Birley } \\
\text { (1997) }\end{array}$ \\
\hline & $\begin{array}{l}\text { Stakeholder-specific } \\
\text { storytelling }\end{array}$ & $\begin{array}{l}\text { If ventures meet } \\
\text { stakeholder require- } \\
\text { ments, they receive } \\
\text { resources from outside } \\
\text { the organization; } \\
\text { stakeholder persuasion } \\
\text { is a common tactic to } \\
\text { preserve resources }\end{array}$ & $\begin{array}{l}\text { Di Domenico et al. (2010); } \\
\text { Kuratko et al. (2015, } \\
\text { 2017) }\end{array}$ \\
\hline & & $\begin{array}{l}\text { Stories define a new ven- } \\
\text { ture in a favorable way, } \\
\text { and therefore offer a } \\
\text { good opportunity to } \\
\text { secure the resource } \\
\text { flow to the new enter- } \\
\text { prise }\end{array}$ & $\begin{array}{l}\text { Lounsbury and Glynn } \\
\text { (2001), O'Kane et al. } \\
\text { (2015) }\end{array}$ \\
\hline & & $\begin{array}{l}\text { Stories of a venture } \\
\text { should be framed to } \\
\text { the specific stake- } \\
\text { holder expectations }\end{array}$ & Fisher et al. (2017) \\
\hline & & $\begin{array}{l}\text { It is crucial for entre- } \\
\text { preneurs to build up } \\
\text { a distinctive image to } \\
\text { attract stakeholders }\end{array}$ & $\begin{array}{l}\text { Lounsbury and Glynn } \\
2001\end{array}$ \\
\hline & Endorsement & $\begin{array}{l}\text { Press reports or compe- } \\
\text { tencies of the endorser } \\
\text { signal that the entity is } \\
\text { trustworthy }\end{array}$ & $\begin{array}{l}\text { Ito (2018), Greene et al. } \\
\quad(1999)\end{array}$ \\
\hline & $\begin{array}{l}\text { Participative strategy } \\
\text { making }\end{array}$ & $\begin{array}{l}\text { In multigenerational } \\
\text { family firms, participa- } \\
\text { tive strategy-making } \\
\text { supports entrepreneur- } \\
\text { ial activities }\end{array}$ & Chirico et al. (2011) \\
\hline \multirow[t]{3}{*}{ Normative legitimacy } & $\begin{array}{l}\text { Fit to corporate values } \\
\text { and norms }\end{array}$ & $\begin{array}{l}\text { Complying with the } \\
\text { socially expected } \\
\text { behavior (values and } \\
\text { norms) can lead to } \\
\text { stakeholder acceptance }\end{array}$ & $\begin{array}{l}\text { Biniari (2011); De Sarbo } \\
\text { et al. (1987); O'Kane } \\
\text { et al. (2015) }\end{array}$ \\
\hline & $\begin{array}{l}\text { Stakeholder-specific } \\
\text { storytelling }\end{array}$ & $\begin{array}{l}\text { Stories define a new } \\
\text { venture in a favorable } \\
\text { way, thereby offering } \\
\text { a good opportunity to } \\
\text { secure the resource } \\
\text { flow to the new enter- } \\
\text { prise }\end{array}$ & $\begin{array}{l}\text { Lounsbury and Glynn } \\
\text { (2001), O'Kane et al. } \\
\text { (2015) }\end{array}$ \\
\hline & & $\begin{array}{l}\text { Stories on a venture } \\
\text { should be framed to } \\
\text { the specific expecta- } \\
\text { tions of stakeholders }\end{array}$ & Fisher et al. (2017) \\
\hline
\end{tabular}




\begin{tabular}{|c|c|c|c|}
\hline Type of legitimacy & Strategy & $\begin{array}{l}\text { Description of the } \\
\text { strategy }\end{array}$ & Studies \\
\hline & & $\begin{array}{l}\text { It is crucial for entre- } \\
\text { preneurs to build up } \\
\text { a distinctive image to } \\
\text { attract stakeholders }\end{array}$ & $\begin{array}{l}\text { Lounsbury and Glynn } \\
\text { (2001) }\end{array}$ \\
\hline \multirow[t]{4}{*}{ Pragmatic legitimacy } & $\begin{array}{l}\text { Linkage with internal } \\
\text { corporate ventures }\end{array}$ & $\begin{array}{l}\text { Develop early linkage } \\
\text { between the venture } \\
\text { and the firm }\end{array}$ & $\begin{array}{l}\text { McGrath (1995); Sykes } \\
\quad(1990)\end{array}$ \\
\hline & $\begin{array}{l}\text { Social action and com- } \\
\text { munity support }\end{array}$ & $\begin{array}{l}\text { An increase in social } \\
\text { action can lead to an } \\
\text { increase in organiza- } \\
\text { tional legitimacy. This } \\
\text { in turn leads to an } \\
\text { increase in the support } \\
\text { from the community. } \\
\text { Community support is } \\
\text { then reflected in larger } \\
\text { stocks of capital that } \\
\text { can be reinvested in } \\
\text { social actions }\end{array}$ & $\begin{array}{l}\text { Moizer and Tracey (2010); } \\
\text { Venugopal and Viswana- } \\
\text { than (2019) }\end{array}$ \\
\hline & Bootlegging behavior & $\begin{array}{l}\text { Employees engage in } \\
\text { activities without } \\
\text { official permission } \\
\text { or supervision. They } \\
\text { often make use of the } \\
\text { organizations' hidden } \\
\text { resources or generate } \\
\text { their own resources }\end{array}$ & $\begin{array}{l}\text { Augsdorfer (2005); } \\
\text { Burgelman (1983); } \\
\text { Globocnik and Salomo } \\
\text { (2015); Tenzer and Yang } \\
\text { (2020) }\end{array}$ \\
\hline & Bricolage & $\begin{array}{l}\text { Intrapreneurial brico- } \\
\text { lage: entrepreneurial } \\
\text { activity within a large } \\
\text { organization character- } \\
\text { ized by the creative } \\
\text { bundling of scarce } \\
\text { resources } \\
\text { Entrepreneurial brico- } \\
\text { lage: creation of new } \\
\text { combinations of exist- } \\
\text { ing resources within a } \\
\text { small enterprise }\end{array}$ & $\begin{array}{l}\text { Halme et al. (2012); Teng } \\
\quad \text { (2007) }\end{array}$ \\
\hline
\end{tabular}

\section{(2) Outcomes}

\begin{tabular}{llll}
\hline Outcome dimensions & Type of the outcome & $\begin{array}{l}\text { Description of the } \\
\text { outcome }\end{array}$ & Studies \\
\hline Resource source & Owner [Family Firms] & $\begin{array}{l}\text { Resource orchestration } \\
\text { helps to realize the } \\
\text { benefits of entrepre- } \\
\text { neurial activities in } \\
\text { family firms }\end{array}$ \\
\hline
\end{tabular}




\begin{tabular}{|c|c|c|c|}
\hline Outcome dimensions & Type of the outcome & $\begin{array}{l}\text { Description of the } \\
\text { outcome }\end{array}$ & Studies \\
\hline & Top Management & $\begin{array}{l}\text { Willingness of top } \\
\text { managers to stimulate } \\
\text { and promote entre- } \\
\text { preneurial activity; } \\
\text { top management } \\
\text { support, including } \\
\text { the provision of } \\
\text { needed resources, } \\
\text { is positively related } \\
\text { to the number of } \\
\text { entrepreneurial ideas } \\
\text { generated }\end{array}$ & $\begin{array}{l}\text { Clark and Ramachan- } \\
\text { dran (2019); Hitt et al. } \\
\text { (1999); Hornsby et al. } \\
\text { (2009); Kuratko et al. } \\
\text { (1990); Lin (2020); } \\
\text { Rogan and Mors } \\
\text { (2016); Srivastava and } \\
\text { Lee (2005); Zahra et al. } \\
\text { (2000) }\end{array}$ \\
\hline & Middle Management & $\begin{array}{l}\text { Middle management } \\
\text { with its key role has a } \\
\text { significant influence } \\
\text { on CE activities } \\
\text { within an organization }\end{array}$ & $\begin{array}{l}\text { Halme et al. (2012); } \\
\text { Hornsby et al. (2002); } \\
\text { Kuratko et al. (2005) }\end{array}$ \\
\hline & Employees & $\begin{array}{l}\text { Employees engage in } \\
\text { activities without } \\
\text { official permission } \\
\text { or supervision. They } \\
\text { often make use of the } \\
\text { organizations' hidden } \\
\text { resources or generate } \\
\text { their own resources }\end{array}$ & $\begin{array}{l}\text { Globocnik and Salomo } \\
\text { (2015); Tenzer and } \\
\text { Yang, (2020) }\end{array}$ \\
\hline & External networks & $\begin{array}{l}\text { Enterprises often lack } \\
\text { business contacts } \\
\text { that are crucial to } \\
\text { letting the business } \\
\text { grow. These gap in } \\
\text { resources can be } \\
\text { provided by network } \\
\text { support }\end{array}$ & $\begin{array}{l}\text { Clarysse and Bruneel } \\
\text { (2007); Teng (2007) }\end{array}$ \\
\hline \multirow[t]{3}{*}{ Resource type } & Financial & $\begin{array}{l}\text { The provision of } \\
\text { financial resources } \\
\text { positively relates } \\
\text { to the number of } \\
\text { entrepreneurial ideas } \\
\text { generated }\end{array}$ & $\begin{array}{l}\text { Greene et al. (1999); } \\
\text { Gassmann and Becker } \\
\text { (2006); Heavey } \\
\text { and Simsek (2013); } \\
\text { Hornsby et al. (2009); } \\
\text { Gurău and Dana (2020) }\end{array}$ \\
\hline & Inspirational & $\begin{array}{l}\text { Top and middle manag- } \\
\text { ers play an important } \\
\text { role in setting an } \\
\text { organizational vision } \\
\text { or environment that } \\
\text { encourages innovation }\end{array}$ & $\begin{array}{l}\text { Heavey and Simsek } \\
\text { (2013); Hitt et al. } \\
\text { (1999); Hornsby et al. } \\
\text { (2002) }\end{array}$ \\
\hline & Human & $\begin{array}{l}\text { Provisioning of talented } \\
\text { human resources to } \\
\text { the venturing activi- } \\
\text { ties }\end{array}$ & $\begin{array}{l}\text { De Bettignies and Chemla } \\
\text { (2008) }\end{array}$ \\
\hline
\end{tabular}




\begin{tabular}{|c|c|c|c|}
\hline Outcome dimensions & Type of the outcome & $\begin{array}{l}\text { Description of the } \\
\text { outcome }\end{array}$ & Studies \\
\hline & Organizational & $\begin{array}{l}\text { Organizational condi- } \\
\text { tions that support } \\
\text { the entrepreneurial } \\
\text { activities }\end{array}$ & $\begin{array}{l}\text { Kanter (1985; Greene } \\
\text { et al. (1999); Hornsby } \\
\text { et al. (2002, 2009); Van- } \\
\text { dermerwe and Birley } \\
\text { (1997) }\end{array}$ \\
\hline & Physical & $\begin{array}{l}\text { Provide infrastructure to } \\
\text { support the entrepre- } \\
\text { neurial activities }\end{array}$ & $\begin{array}{l}\text { Greene et al. (1999); Van- } \\
\text { dermerwe and Birley } \\
\text { (1997); Gassmann and } \\
\text { Becker (2006) }\end{array}$ \\
\hline & Political & $\begin{array}{l}\text { Support in political } \\
\text { processes to mobilize } \\
\text { scarce resources }\end{array}$ & Fulop (1991) \\
\hline & Time & $\begin{array}{l}\text { Time availability of } \\
\text { stakeholders as } \\
\text { resource for generat- } \\
\text { ing entrepreneurial } \\
\text { outcomes }\end{array}$ & $\begin{array}{l}\text { Bertels et al. (2020); } \\
\text { Hornsby et al. (2002, } \\
\text { 2009) }\end{array}$ \\
\hline & \multirow[t]{3}{*}{ Knowledge } & $\begin{array}{l}\text { Explicit and implicit } \\
\text { knowledge from com- } \\
\text { pany to CE entity }\end{array}$ & $\begin{array}{l}\text { Gassmann and Becker } \\
\text { (2006); Gurău and Dana } \\
\text { (2020) }\end{array}$ \\
\hline & & $\begin{array}{l}\text { Intellectual capital } \\
\text { and top management } \\
\text { team diversity have } \\
\text { a positive influence } \\
\text { on innovation and } \\
\text { venturing activities }\end{array}$ & $\begin{array}{l}\text { Hayton (2005); Srivas- } \\
\text { tava and Lee (2005); } \\
\text { Gassmann and Becker } \\
(2006)\end{array}$ \\
\hline & & $\begin{array}{l}\text { Top managers try to } \\
\text { grow beyond the lim- } \\
\text { its set by the resources } \\
\text { they currently } \\
\text { control, with the aim } \\
\text { of acquiring more } \\
\text { technology investment } \\
\text { in their firm. Exploit- } \\
\text { ing technologically } \\
\text { skilled people and the } \\
\text { development of tech- } \\
\text { nological distinctive } \\
\text { competencies increase } \\
\text { corporate entrepre- } \\
\text { neurship }\end{array}$ & $\begin{array}{l}\text { De Bettignies and Chemla } \\
\text { (2008); García-Morales } \\
\text { et al. (2014) }\end{array}$ \\
\hline & Social / Relational & $\begin{array}{l}\text { A (social) network is } \\
\text { useful to find further } \\
\text { resources and offer } \\
\text { trust; Bricoleurs make } \\
\text { use of their various } \\
\text { networks to mobilize } \\
\text { resources }\end{array}$ & $\begin{array}{l}\text { Greene et al. (1999); Teng } \\
\text { (2007) }\end{array}$ \\
\hline
\end{tabular}




\begin{tabular}{|c|c|c|c|}
\hline Outcome dimensions & Type of the outcome & $\begin{array}{l}\text { Description of the } \\
\text { outcome }\end{array}$ & Studies \\
\hline \multirow[t]{3}{*}{ Resource dynamics } & $\begin{array}{l}\text { Deployment of } \\
\text { Resources }\end{array}$ & $\begin{array}{l}\text { Often decisions must } \\
\text { be made whether } \\
\text { the resources are } \\
\text { allocated to the core } \\
\text { company or the new } \\
\text { venture }\end{array}$ & Basu and Wadhwa (2013) \\
\hline & $\begin{array}{l}\text { Withdrawal of } \\
\text { Resources }\end{array}$ & $\begin{array}{l}\text { Entrepreneurs often } \\
\text { need external support } \\
\text { to assess the profit- } \\
\text { ability and feasibility } \\
\text { of their idea. Without } \\
\text { external support they } \\
\text { lack resources }\end{array}$ & Teng (2007) \\
\hline & $\begin{array}{l}\text { New Combinations of } \\
\text { Resources }\end{array}$ & $\begin{array}{l}\text { Entrepreneurial innova- } \\
\text { tions more concerned } \\
\text { with exploration of } \\
\text { new combinations of } \\
\text { resources than with } \\
\text { the optimizing exist- } \\
\text { ing ones }\end{array}$ & $\begin{array}{l}\text { Gurău and Dana (2020); } \\
\text { Ravasi and Turati } \\
\text { (2005); Teng (2007); } \\
\text { Westhead and Wright } \\
\text { (1998) }\end{array}$ \\
\hline
\end{tabular}

Funding Open Access funding enabled and organized by Projekt DEAL.

\section{Declarations}

Conflict of interest The authors declare that they have no conflict of interest.

Open Access This article is licensed under a Creative Commons Attribution 4.0 International License, which permits use, sharing, adaptation, distribution and reproduction in any medium or format, as long as you give appropriate credit to the original author(s) and the source, provide a link to the Creative Commons licence, and indicate if changes were made. The images or other third party material in this article are included in the article's Creative Commons licence, unless indicated otherwise in a credit line to the material. If material is not included in the article's Creative Commons licence and your intended use is not permitted by statutory regulation or exceeds the permitted use, you will need to obtain permission directly from the copyright holder. To view a copy of this licence, visit http://creativecommons.org/licen ses/by/4.0/.

\section{References}

Ahuja SB (2019) Why innovation labs fail, and how to ensure yours doesn't. Harvard Business Review. Available online at https://hbr.org/2019/07/why-innov ation-labs-fail-and-how-to-ensure-yours-doesnt

Aldrich HE, Fiol CM (1994) Fools rush in? The institutional context of industry creation. Acad Manag Rev 19:645-670

Augsdorfer P (2005) Bootlegging and path dependency. Res Policy 34(1):1-11

Basu S, Wadhwa A (2013) External venturing and discontinuous strategic renewal: an options perspective. J Prod Innov Manag 30(5):956-975 
Behrens J, Patzelt H (2016) Corporate entrepreneurship managers' project terminations: integrating portfolio-level, individual-level, and firm-level effects. Entrep Theory Pract 40(4):815-842

Bertels HM, Mithani M, Zhu S, Koen PA (2020) Corporate champions of early stage project proposals and the insitutionalisation of organisational inertia. Int J Innov Manag 24(3):1-30

Biniari M (2011) The emotional embeddedness of corporate entrepreneurship: The case of envy. Entrep Theory Pract 36(1):141-170

Booth A, Papaioannou D, Sutton A (2012) Systematic approaches to a successful literature review, 2nd edn. Sage Publications, Beverly Hills

Bouchard V, Fayolle A. (2017) Corporate entrepreneurship. Routledge: Taylor \& Francis Group: New York, Springer Gabler Verlag: Wiesbaden.

Burgelman RA (1983) A model of the interaction of strategic behavior, corporate context, and the concept of strategy. Acad Manag Rev 8(1):61-70

Burgelman RA (1985) Managing new venture division: research finding and implications for strategic management. Strateg Manag J 6(1):39-54

Chirico F, Sirmon DG, Sciascia S, Mazolla P (2011) Resource orchestration in family firms: Investigating how entrepreneurial orientation, generational involvement, and participative strategy affect performance. Strateg Entrep J 5(4):307-326

Clark K, Ramachandran I (2019) subsidiary entrepreneurship and entrepreneurial opportunity: an institutional perspective. J Int Manag 25(1):37-50

Clarysse B, Bruneel J (2007) Nurturing and growing innovative start-ups: the role of policy as integrator. R\&D Manag 37(2):139-149

Corbett A, Covin JG, O' Connor GC, Tucci CL (2013) Corporate entrepreneurship: state-of-the-art research and a future research agenda. J Prod Innov Manag 30(5):812-820

Corbett A, Neck H, Detienne D (2007) How corporate entrepreneurs learn from fledgling innovation initiatives: cognition and the development of a termination script. Entrep Theory Pract 31(6):829-852

Covin J, Miles M (1999) Corporate entrepreneurship and the pursuit of competitive advantage. Entrep Theory Pract 32(3):47-63

Dalziel T, Gentry R, Bowerman M (2011) an integrated agency-resource dependence view of the influence of directors' human and relational capital on firms' R\&D spending. J Manage Stud 48(6):1217-1242

De Bettignies JE, Chemla G (2008) Corporate venturing, allocation of talent, and competition for star managers. Manage Sci 54(3):505-521

De Clercq D, Dimov D, Thongpapanl N (2013) Organizational social capital, formalization, and internal knowledge sharing in entrepreneurial orientation formation. Entrep Theory Pract 37(3):505-537

De Massis A, Eddleston K, Rovelli P (2021) Entrepreneurial by design: how organizational design affects family and non-family firms' opportunity exploitation. J Manag Stud 58(1):27-62

Denyer D, Tranfield D (2009) Producing a systematic review. In: Buchanan DA, Bryman A (eds) The Sage handbook of organizational research methods. Sage Publications Ltd, pp 671-689

De Sarbo W, MacMillan IC, Day DL (1987) Criteria for corporate venturing: importance assigned by managers, University of Pennsylvania. J Bus Ventur 2(4):329-350

Di Domenico M, Haugh H, Tracey P (2010) Social bricolage: theorizing social value creation in social enterprises. Entrep Theory Pract 34(4):681-703

Drori H, Honig B (2013) A process model of internal and external legitimacy. Organ Stud 34(3):345-376

Engelen A, Kaulfersch A, Schmidt S (2016) The contingent role of top management's social capital on the relationship between entrepreneurial orientation and performance. J Small Bus Manag 54(3):827-850

Fisch C, Block J (2018) Six tips for your (systematic) literature review in business and management research. Manag Rev Q 68:103-106

Fisher G, Kuratko DF, Bloodgood JM, Hornsby JS (2017) Legitimate to whom? The challenge of audience diversity and new venture legitimacy. J Bus Ventur 32(1):52-71

Frandsen S, Morsing M, Vallentin S (2013) Adopting sustainability in the organization. J Manag Dev 32(3):236-246

Frey BS, Rost K (2010) Do rankings reflect research quality? J Appl Econ 13(1):1-38

Fulop L (1991) Middle managers: victims or vanguards of the entrepreneurial movement? J Manag Stud 28(1):25-44

García-Morales VJ, Bolívar-Ramos MT, Martín-Rojas R (2014) Technological variables and absorptive capacity's influence on performance through corporate entrepreneurship. J Bus Res 67:1468-1477 
Garrett RP Jr, Neubaum DO (2013) Top management support and Initial strategic assets: a dependency model for internal corporate venture performance. J Prod Innov Manag 30(5):896-915

Gassmann O, Becker B (2006) Towards a resource-based view of corporate incubators. Int J Innov Manag 10(1):19-45

Globocnik D, Salomo A (2015) Do formal management practices impact the emergence of bootlegging behavior? J Prod Innov Manag 32(4):505-521

Greene PG, Brush CG, Hart MM (1999) The corporate venture champion: a resource-based approach to role and process. Entrep Theory Pract 23(3):103-122

Gurău C, Dana LP (2020) Financing paths, firms' governance and corporate entrepreneurship: accessing and applying operant and operand resources in biotechnology firms. Technol Forecast Soc Chang 153:1-12

Gutmann T (2019) Harmonizing corporate venturing modes: an integrative review and research agenda. Manag Rev Q 69:121-157

Halme M, Lindeman S, Linna P (2012) Innovation for inclusive business: intrapreneurial bricolage in multinational corporations. J Manage Stud 49(4):743-784

Hayton JC (2005) Competing in the new economy: the effect of intellectual capital on corporate entrepreneurship in high-technology new ventures. R\&D Manag 35(2):137-155

Heavey C, Simsek Z (2013) Top management compositional effects on corporate entrepreneurship: the moderating role of perceived technological uncertainty. J Prod Innov Manag 30(5):837-855

Hill S, Birkinshaw J (2008) Strategy-organization configurations in corporate venture units: Impact on performance and survival. J Bus Ventur 23(4):423-444

Hitt MA, Nixon RD, Hoskisson RE, Kochhar R (1999) Corporate entrepreneurship and cross-functional fertilization: activation, process and desintegration of a new product design team. Entrep Theory Pract 23(3): 145-168

Hitt MA, Ireland RD, Sirmon DG, Trahms CA (2011) Strategic entrepreneurship: creating value for individuals, organizations, and society. Acad Manag Perspect 25(2):57-75

Hornsby JS, Kuratko DF, Zahra SA (2002) Middle managers' perception of the internal environment for corporate entrepreneurship: assessing a measurement scale. J Bus Ventur 17(3):253-273

Hornsby JS, Kuratko DF, Sheperd DA, Bott JP (2009) Managers' corporate entrepreneurial actions: examining perceptions and positions. J Bus Ventur 24(3):236-247

Ito Y (2018) Interorganizational business development utilizing legitimacy for resource mobilization in large firms: successful and unsuccessful cases. Ind Mark Manag 75:80-89

Jiang X, Liu H, Fey C, Jiang F (2018) Entrepreneurial orientation, network resource acquisition, and firm performance: a network approach. J Bus Res 87:46-57

Kanter R (1985) Supporting innovation and venture development in established companies. J Bus Ventur $1(1): 47-60$

Kelley D (2011) Sustainable corporate entrepreneurship: evolving and connecting with the organization. Bus Horiz 54(1):73-83

Kostova T, Roth K (2002) Adoption of an organizational practice by subsidiaries of multinational corporations: institutional and relational effects. Acad Manag J 45(1):215-233

Kostova T, Zaheer S (1999) Organizational legitimacy under conditions of complexity: the case of the multinational enterprise. Acad Manag Rev 24(1):64-81

Kuckertz A (2017) Management: corporate entrepreneurship. Springer Gabler Verlag, Wiesbaden

Kuratko DF, Audretsch DB (2013) Clarifying the domains of corporate entrepreneurship. Int Entrep Manag J 9(3):323-335

Kuratko DF, Fisher G, Bloodgood JM, Hornsby JF (2017) The paradox of new venture legitimation within an entrepreneurial ecosystem. J Small Bus Econ 49(1):119-140

Kuratko DF, Hornsby J, Hayton JC (2015) Corporate entrepreneurship: the innovative challenge for a new global economic reality. J Small Bus Econ 45(2):245-253

Kuratko DF, Ireland RD, Covin JG, Hornsby JC (2005) A model of middle-level managers' entrepreneurial behavior. Entrep Theory Pract 29(6):699-716

Kuratko DF, Montagno RV, Hornsby JS (1990) Developing an intrapreneurial assessment instrument for an effective corporate entrepreneurial environment. Strateg Manag J 11:49-58

Lampe J, Kraft PS, Bausch A (2020) Mapping the field of research on entrepreneurial organizations (1937-2016): a bibliometric analysis and research agenda. Entrep Theory Pract 44(4):784-816

Lin J-Y (2020) What affects new venture firm's innovation more in corporate venture capital? Eur Manag J 38(4):646-660 
Lounsbury M, Glynn MA (2001) Cultural entrepreneurship: stories, Legitimacy, and the acquisition of resources. Strateg Manag J 22:545-564

Martin-Rojas R, Garcia-Morales VJ, Gonzalez-Alvarez N (2019) Technological antecedents of entrepreneurship and its consequences for organizational performance. Technol Forecast Soc Chang 147:22-35

Ma H, Liu TQ, Karri R (2016) Internal corporate venturing: intrapreneurs, institutions, and initiatives. Organ Dyn 45(2):114-123

Marvel M, Griffin A, Hebda J, Vojak B (2007) Examining the technical corporate entrepreneurs' motivation: voices from the field. Entrep Theory Pract 31(5):753-768

McGrath RG (1995) Advantage from adversity: learning from disappointment in internal corporate ventures. J Bus Ventur 10(2):121-142

Meyer JW, Rowan B (1977) Institutionalized organizations: formal structure as myth and ceremony. Am J Sociol 83(2):340-363

Miao C, Coombs JE, Qian S, Sirmon DG (2017) The mediating role of entrepreneurial orientation: a meta-analysis of resource orchestration and cultural contingencies. J Bus Res 77:68-80

Miller A, Spann MS, Lerner L (1991) Competitive advantages in new corporate ventures: the impact of resource sharing and reporting level. J Bus Ventur 6(5):335-350

Miller R (2016) Coca-Cola closes founders startup incubator. In TechCrunch, 12/29/2016. Available online at https://techcrunch.com/2016/12/29/coca-cola-reportedly-closes-founders-startup-incub ator

Moizer J, Tracey P (2010) Strategy making in social enterprise: the role of resource allocation and its effects on organizational sustainability systems. Res Behav Sci 27:252-266

Morris MH, Kuratko DF, Covin JG (2011) Corporate entrepreneurship and innovation, 3rd edn. Cengage/ Thomson South-Western, Mason

O'Kane C, Mangematin V, Geoghegan W, Fitzgerald C (2015) University technology transfer offices: the search for identity to build legitimacy. Res Policy 44(2):421-437

Park H, Auh S, Maher A, Singhapakdi A (2012) Marketing's accountability and internal legitimacy: implications for firm performance. J Bus Res 65(11):1576-1582

Ravasi D, Turati C (2005) Exploring entrepreneurial learning: a comparative study of technology development projects. J Bus Ventur 20(1):137-164

Röhm P (2018) Exploring the landscape of corporate venture capital: a systematic review of the entrepreneurial and finance literature. Manag Rev Q 68:279-319

Rogan M, Mors ML (2016) Managerial networks and exploration in a professional service firm. Organ Stud 38(2):225-249

Sakhdari K (2016) Corporate entrepreneurship: a review and future research agenda. Technol Innov Manag Rev 6(8):5-18

Schulte L (2021) Integrating immediate gains with sustainable performance: systematic review of paradox at the intersection of strategic management and innovation. Manag Rev Q. https://doi.org/10. 1007/s11301-021-00225-w

Skarmeas D, Lisboa A, Saridakis C (2016) Export performance as a function of market learning capabilities and intrapreneurship: SEM and FsQCA findings. J Bus Res 69(11):5342-5347

Shrader R, Simon M (1997) Corporate versus independent new ventures: resource, strategy, and performance differences. J Bus Ventur 12(1):47-66

Spanjol J, Tam L, Qualls WJ, Bohlmann JD (2011) New product team decision making: regulatory focus effects on number, type, and timing decisions. J Prod Innov Manag 28(5):623-640

Srivastava A, Lee H (2005) Predicting order and timing of new product moves: the role of top management in corporate entrepreneurship. J Bus Ventur 20(4):459-481

Suchman MC (1995) Managing legitimacy: strategic and institutional approaches. Acad Manag Rev 20(3):571-610

Suddaby R, Bitektine A, Haack P (2017) Legitimacy. Acad Manag Ann 11(1):451-478

Sykes HB (1990) Corporate venture capital: strategies for success. J Bus Ventur 5(1):37-47

Sykes HB, Block Z (1989) Corporate venturing obstacles: sources and solutions. J Bus Ventur 4(3):159-167

Tchokogué A, Paché G, Nollet J, Stoleru R (2017) Intra-organizational legitimization strategies used by purchasing managers. J Purch Supply Manag 23(3):163-175

Teng BS (2007) Corporate entrepreneurship activities through strategic alliances: a resource-based approach toward competitive advantage. J Manag Stud 44:119-142 
Tenzer H, Yang P (2020) The impact of organisational support and individual achievement orientation on creative deviance. Int J Innov Manag 24(2):2050020

Tracey P, Dalpiaz E, Phillips N (2018) Fish out of water: translation, legitimation, and new venture creation. Acad Manag J 61(5):1627-1666

Tranfield D, Denyer D, Smart P (2003) Towards a methodology for developing evidence-informed management knowledge by means of systematic review. Br J Manag 14(3):207-222

Vandermerwe S, Birley S (1997) The corporate entrepreneur: leading organizational transformation. Long Range Plan 30(3):345-352

Venugopal S, Viswanathan M (2019) Implementation of social innovations in subsistence marketplaces: a facilitated institutional change process model. J Prod Innov Manag 36(6):800-823

Wang T, Thornhill S, DeCastro SO (2017) Entrepreneurial orientation, legitimation, and new venture performance. Strateg Entrep J 11:373-392

Weiss L, Kanbach DK (2021) Toward an integrated framework of corporate venturing for organizational ambidexterity as a dynamic capability. Manag Rev Q. https://doi.org/10.1007/s11301-021-00223-y

Westhead P, Wright M (1998) Novice, Portfolio, and serial founders: are they different? J Bus Ventur 13(3):173-204

Wiklund J, Shepherd D (2003) Knowledge-based resources, entrepreneurial orientation, and the performance of small and medium-sized businesses. Strateg Manag J 24(13):1307-1314

Wu W-Y, Chang M-L, Chen C-W (2008) Promoting innovation through the accumulation of intellectual capital, social capital, and entrepreneurial orientation. R\&D Manag 38(3):265-277

Yang G, Wang R (2013) The institutionalization of an electronic marketplace in China. J Prod Innov Manag 30(1):96-109

Yiu D, Lau C (2008) Corporate entrepreneurship resource capital configuration in emerging market firms. Entrep Theory Pract 32(1):37-57

Yusubova A, Andries P, Clarysse B (2019) The role of incubators in overcoming technology venture's resource gaps at different development stages. R\&D Manag 49(5):803-818

Zahra S, Neubaum D, Huse M (2000) Entrepreneurship in medium-size companies: exploring the effects of ownership and governance systems. J Manag 26(5):947-976

Zampetakis L, Beldekos P, Moustakis V (2009) "Day-to-day" entrepreneurship within organisations: the role of trait emotional intelligence and perceived organisational support. Eur Manag $\mathrm{J}$ 27(3):165-175

Zimmerman MA, Zeitz GJ (2002) Beyond survival: achieving new venture growth by building legitimacy. Acad Manag Rev 27(3):414-431

Publisher's Note Springer Nature remains neutral with regard to jurisdictional claims in published maps and institutional affiliations. 